\title{
DISAPPEARED HISTORIC OPEN SPACES IN THE CENTER OF SAINT PETERSBURG
}

\author{
Leonid Lavrov¹, Fedor Perov² \\ 1,2 Saint Petersburg State University of Architecture and Civil Engineering \\ 2-ya Krasnoarmeiskaya st., 4, St. Petersburg, Russia \\ ${ }^{1}$ leonid.lavrov@gmail.com
}

\begin{abstract}
The paper questions the official statement that the system of open spaces in the historic center of Saint Petersburg has preserved the "authenticity of its chief components". Conditions for the formation and subsequent reconstructions of Theater Square and areas adjacent to the Neva river are analyzed.

The nature and scope of changes those areas undergone in the latter half of the 19th and early 20th centuries are identified. It is shown that Senate, Admiralty, Rumyantsev, Collegiate squares and Razvodnaya ground (used for the changing of the guard) lost their transparency which disturbed the relationship between the Neva water area and city open spaces, and that significant damage was caused to the city center panorama. It is noted that the center landscape potential was neglected due to that reason. Proposals are made to recreate the lost transparency of the city center public spaces.
\end{abstract}

\author{
Keywords \\ Landscapes of the historic center of Saint Petersburg, open spaces, reconstruction.
}

\section{Introduction}

It is generally acknowledged that one of the architectural features of the Saint Petersburg historic center is its "single continuous open space formed by rivers and canals, squares, avenues, streets and gardens" (Shvidkovsky, 2007). When Saint Petersburg was suggested to be included in the World Heritage List, the corresponding Retrospective Statement of Outstanding Universal Value of the World Heritage Site "Historic Center of Saint Petersburg and Related Groups of Monuments" pointed to the specific character of its spatial framework as a substantial argument: "The fullflowing Neva bequeathed the city an exceptional spatial scale and wealth of spectacle...

The Neva water spaces were natural extensions of the system of city squares" (Retrospective Statement of Outstanding Universal Value of the World Heritage Site "Historic Center of Saint Petersburg and Related Groups of Monuments"). It was further emphasized that "the initial city layout and a large portion of the original structures in Saint Petersburg's historic centre are testament to its Outstanding Universal Value... integrated value as the Historic Urban Landscape." However, the suggested opinion that "the site has preserved the authenticity of its chief components" seems overoptimistic. The present paper deals with the reliability of such assertion. Moreover, it is clarified to what extent the information on the development pattern can be used to assess the state of urban landscapes.

\section{Terms and Definitions}

An analysis of terms used to describe open spaces in various fields of urban planning revealed some fundamental discrepancies in definitions of key concepts.

"Public spaces represent a part of the urban environment that is constantly available for people 


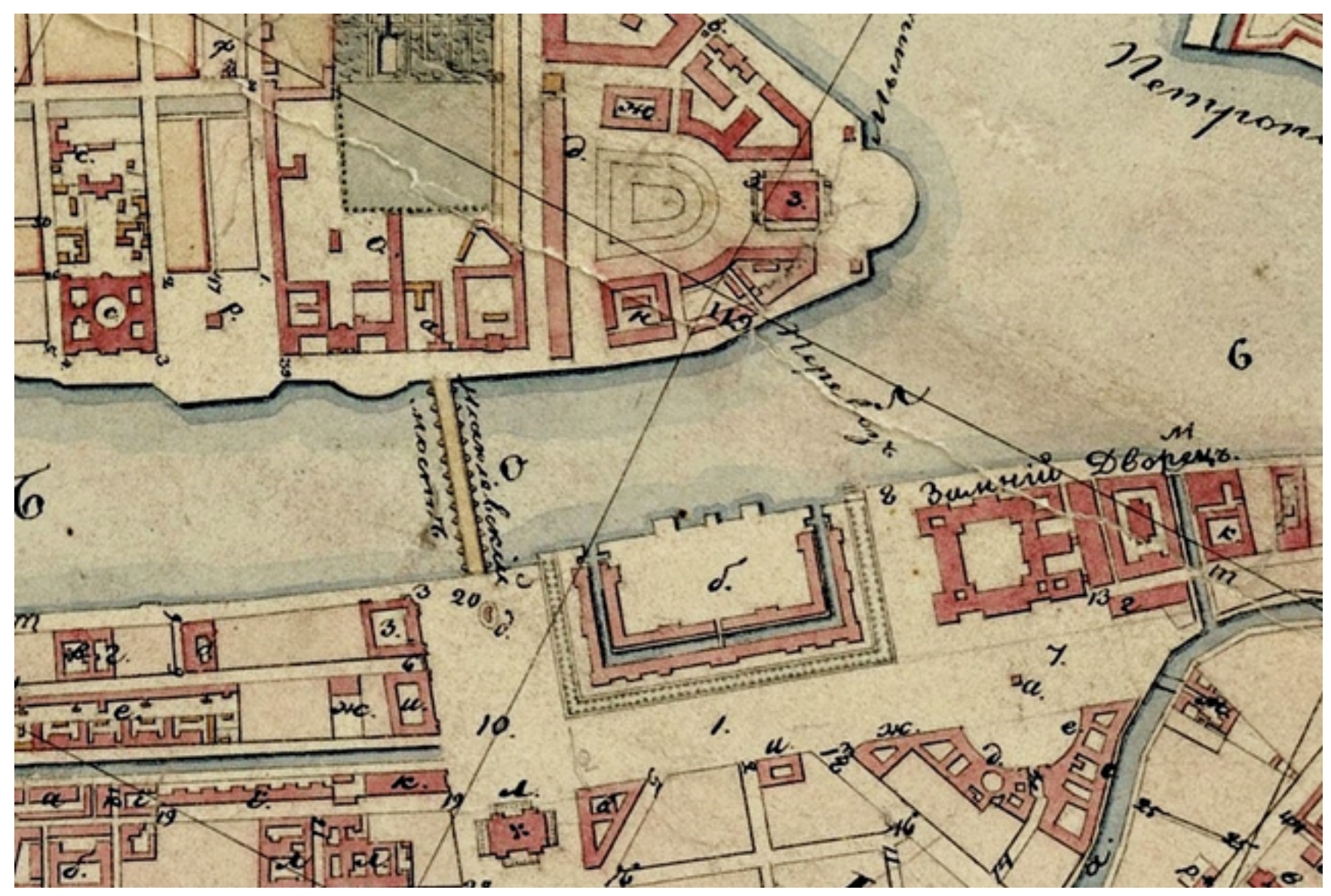

Figure 1. A map showing the system of Saint Petersburg open spaces at its golden age

free of charge... among places where urban social life takes place, the following can be mentioned: squares, embankments, streets, pedestrian areas, parks" (http:// estp-blog.ru/encyclopedia/13956/).

The commonly used definition suggested by the Central Research and Design Institute for Urban Development qualifies "undeveloped territories in general, including water and park systems, main avenues, embankments, esplanades, pedestrian areas, squares, boulevards and other elements of the urban planning pattern that form a system of open spaces" as urban open spaces. Such approach is reflected in black-and-white urban planning layouts where areas occupied by permanent structures are highlighted ("schwarzplan"). It is understood that white spots represent undeveloped "open" spaces. Such information can be useful when handling construction projects, laying utility lines, etc., but it is insufficient to assess visual characteristics. In particular, gradation of urban green areas by their visual characteristics existing in landscaping is not considered. Green construction comprises the following:

- enclosed spaces (areas and groups of tree plantations that exclude or substantially limit visual connections);

- semi-open spaces (with deeper visibility, greater visual connections with adjacent areas);

- open spaces (glades, ponds, areas not occupied by dense plantations and facilities) (https://znaytovar.ru/ gost/2/Metodicheskoe_rukovodstvoMetod2.html).
Thus, it turns out that undeveloped green areas which are automatically qualified by city planners as open spaces may actually belong to enclosed spaces in terms of landscaping.

The influence of greenery planting on landscapes in Saint Petersburg was noted by B.M. Kirikov in the latter half of the 19th century. He treated the concepts of "openness" and "transparency" as synonyms and stated that in the period under review the city "was losing its openness, transparency... Petersburg began "to fear the emptiness". The city... sort of sought to absorb the area (through development of areas or greenery planting)" (Kirikov, 2006).

A classic example of open space is a city square. According to the Internet, "a square is an architecturally organized open space surrounded by buildings and green areas, being a part of the urban space system" (http://dic. academic.ru/dic.nsf/ruwiki/1778770).

In summary, it can be noted that transparency of an open space, i.e. absence of interferences with the visual perception of its limiting elements (e.g. facade fronts outlining the square), shall be considered as the determining feature of an open space.

\section{Squares of Saint Petersburg}

Evolution of Saint Petersburg development is characterized by the fact thatcentral Palace, Mikhailovskaya and Saint Isaac's squares which made the city famous 
were formed on the basis of the "Alexander's Empire Style" over a short period - in the 1800-1840s. Although, a plan for their formation developed by the Commission for Saint Petersburg and Moscow Stone Construction existed since the 1760s. Indeed, outlines of the squares could be seen on official maps, but the plans were implemented later. A book published by J.G. Georgi in 1794 lists few squares of the late 18th century on the Admiralty side: "irregular Petrovskaya and St. Isaac's squares", "Palace square in the form of an amphitheater", "Tsaritsyn meadow near the Summer Gardens, a square near the Kamenny Theatre and Sennaya square". Vasilyevsky Island had a "large irregular, unpaved, partially swampy square surrounded by the buildings of the Academy of Sciences, State Collegia, Stock Exchange and Customs storehouses" and a "four-cornered empty space" on the banks of the Neva river at the Academy of Arts (Georgi, 2001b) .

The situation began to change rapidly at the very beginning of the 19th century. Saint Petersburg was developing fast. Its population was already over 200,000 people, and the city was among the leading European metropolises. Young Emperor Alexander I ascended the throne. He perceived the renewal of the capital appearance as an important personal task. In the 18001840s, Saint Petersburg matched to the intention of Peter the Great - an image of an imperial city was created. In this short period, a magnificent ensemble of Saint Petersburg central squares was formed which gave the city features of a world-class capital.

\section{Theater square}

This square holds a special place in the city's history: first, it became the first regular square of the city; second, reconstructions performed here were more radical than in any other square of the historic center, therefore, its modern appearance almost does not remind the remarkable past.

In his description of Saint Petersburg in the late 18th century, J.G. Georgi mentioned "a square near the Kamenny Theater" (nowadays it is Theater Square). It was a new urban-planning project, history of which began in 1775, when, at a wasteland that was allocated for residential buildings, theater construction began according to a design of A. Rinaldi. Over a short period (1782-1787), a navigable canal was constructed from the Moyka river to the Fontanka river, and Lithuanian castle (architect I.E. Starov) and Lithuanian market (architect G. Quarenghi) were built on its banks. Outlines of the rectangular square were denoted by houses of local inhabitants. There is no information about any projects for its development - the appearance of a regular urban-planning organism was a result of a strict system of city development management, effect of construction regulations. By the end of the 18th century, a regular public open space was formed here. The square is characterized by large dimensions and compositional symmetry. Its image was determined by the following dominant elements: the theater building, the arcades of the Lithuanian market included in its space, and the Kryukov canal with its granite embankments and ornamental fencing (Figure 2).

In 1801-1803, by order of Alexander I, Thomas de Thomon reconstructed the Bolshoi Kamenny Theater, which radically changed the nature of its appearance and assigned the square a new role of a center of city public life. Numerous works of Saint Petersburg landscape painters (including F.Ya. Alekseev, K.P. Beggrov, G. Quarenghi, K. Kollman, G.L. Lory and M.G. Lory, A.E. Martynov, A. Mayer, B. Patersen, J. B. De la Traverse) testify to its popularity. Their works demonstrate that the first parade square in Saint Petersburg was formed and actively functioned around the Bolshoi Kamenny Theater: at that time there still was a system of fortifications around the Admiralty, and the site of future Mikhailovskaya Square had a marshy swamp - the origin of the Glukhaya river.

In 1849, a finishing stroke was given to the Theater Square - in its center, right on the bank of the Kryukov canal, Imperial Circus Theater was built. "In terms of architecture, the sovereign had a bad taste and chose an extremely unsuccessful location for his pet project, the first permanent circus in Saint Petersburg," wrote wellknown Saint Petersburg expert L. Lurie (Printseva, 2016). The circus theater burned down in 1859, but Mariinsky Theater was quickly erected in its place. Later it was expanded several times. Despite the protests of the art

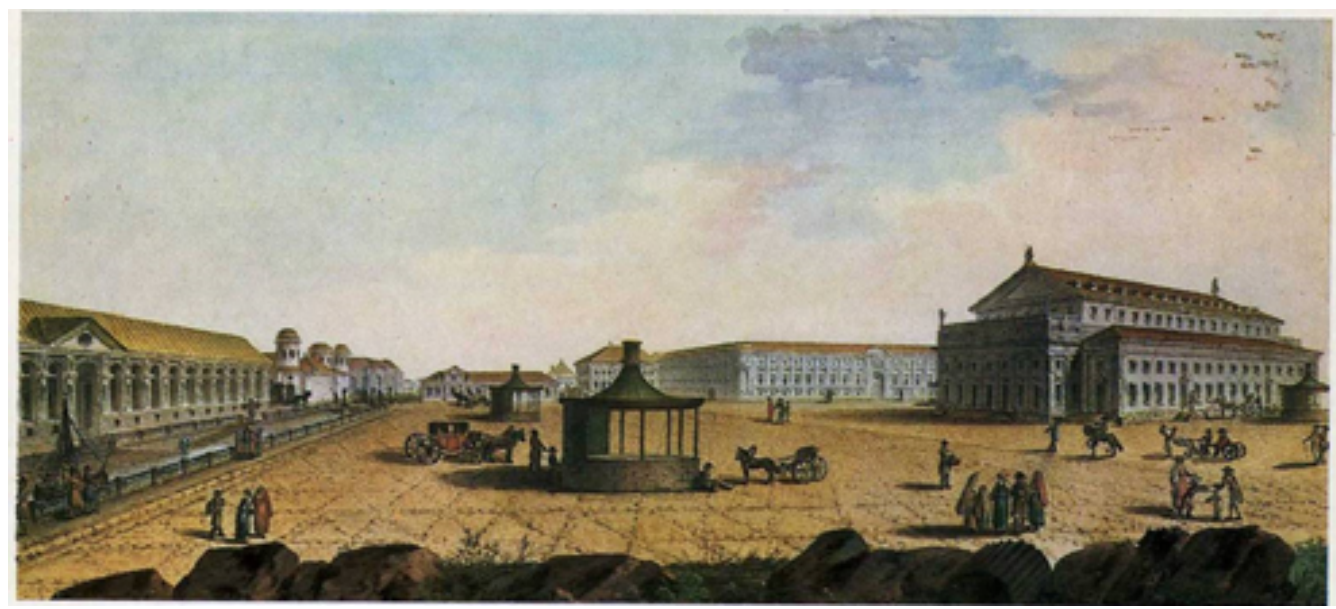

Figure 2. Theater Square in the late 18th century. The Bolshoi Theater in Saint Petersburg. A fragment (by Jean Balthazard De la Traverse, from the collection of I.S. Zilbershteyn) 

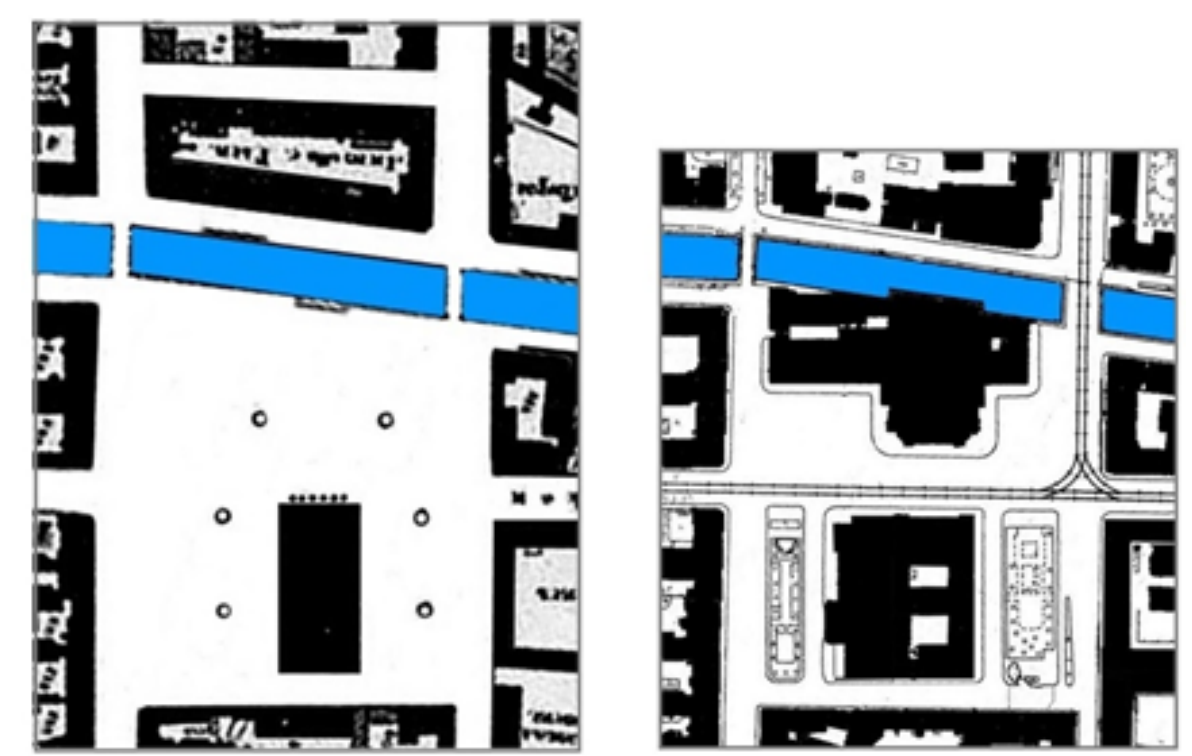

Figure 3. A layout of Theater Square in the early 19th century (left) and in the late 20th century (right)

community, the dilapidated Kamenny Theater was rebuilt for the needs of the Conservatory. Results of the buildings' reconstruction were summarized by A.N. Benois in 1902: "In place of the Bolshoi Theater by de Thomon, a hideous construction consisting of half a dozen "facades", like those that are drawn by first-year students, suddenly appeared... Trying to keep up with its neighbor, the Mariinsky Theater dressed up in a clownish outfit of the so-called "Deutsche Renaissance" (Benois, 1902).

The open space of the square shrank and split up into several parts; it was cut off from the water area of the Kryukov canal and from the arcade of the Lithuanian market. The style of dominant buildings completely changed, urban amenities became different. In the early 19th century, the square near the Kamenny Theater could be compared with Saint Isaac's or Palace square, but by the early 20th century it became similar to unimpressive European squares of the era of commercial construction. We can only regret that the brilliant past of Theater Square is over and nowadays it rarely attracts attention of both experts and lovers of the Saint Petersburg antique. Perhaps, this is due to the fact that only a few background buildings remained from the first regular square. There is no hope that Theater Square will regain its former glory and Saint Petersburg artists will strive to capture its beauty.

\section{Collegiate square}

At first, is was formed as a main square of the new capital, but later it became a storage area for the port, and then it was converted into an area of a palace medical clinic.

In a description of Saint Petersburg of the late 18th century, a "large irregular, unpaved, partially swampy square surrounded by the buildings of the Academy of Sciences, State Collegia, Stock Exchange and Customs storehouses" is mentioned (Georgi, 2001b).

Its name was not mentioned. At that time, it was called Collegiate square (in honor of the building of the
Twelve Collegia) or Academic meadow (reflecting the semi-rural nature of the space near the Academy of Sciences buildings). Collegiate square was the first major urban-planning project which began to take shape on the deserted Vasilyevsky Island. In the early 1720s, outlines of residential quarters were just beginning to appear, soldiers and builders were sleeping in huts and tents, and stone buildings of the Twelve Collegia with a 400-meter facade and Customs merchant center with a 700-meter perimeter emerged at the Spit.

There were no such giant buildings, which were supposed to demonstrate Europe the greatness of the new Russian capital, at a distance of hundreds of miles neither in Russia nor in the Baltic countries. However, such ambitious plans required tremendous efforts. The soil under the future main administrative building of the Russian Empire turned out to be extremely swampy. In order to achieve the desired architectural effect, it was necessary to fill the swamp with soil and stones. 250 people operating ten pile drivers drove dozens of piles into the ground each day (http://www.ipetersburg.ru/zdaniedvenadcati-kollegiy/). More than 2,000 piles formed the foundation base. A canal for drainage was dug along the main facade (Sorokin, Semenov, 2003). By the middle of the 1730s the construction works were completed. The main 400-meter facade of the Twelve Collegia began to face the central water area of the Neva river.

Further reclamation of the swampy lowland slowed down. It was decided to reduce the amount of construction works and outline the area along the perimeter by trade galleries only. Peter I believed that such shops would revive the area. The collegia (administrative institutions) located in the area and the "cabinet of rarities" (the first Russian museum) nearby could attract only few people. There is evidence to the fact that the chief attendant at the Kunstkamera was allocated 400 rubles a year to treat the visitors. That bait was long used. "According to J. Staehlin, even during the reign of Empress Anna loannovna, the visitors were treated with coffee, sandwiches or vodka, 


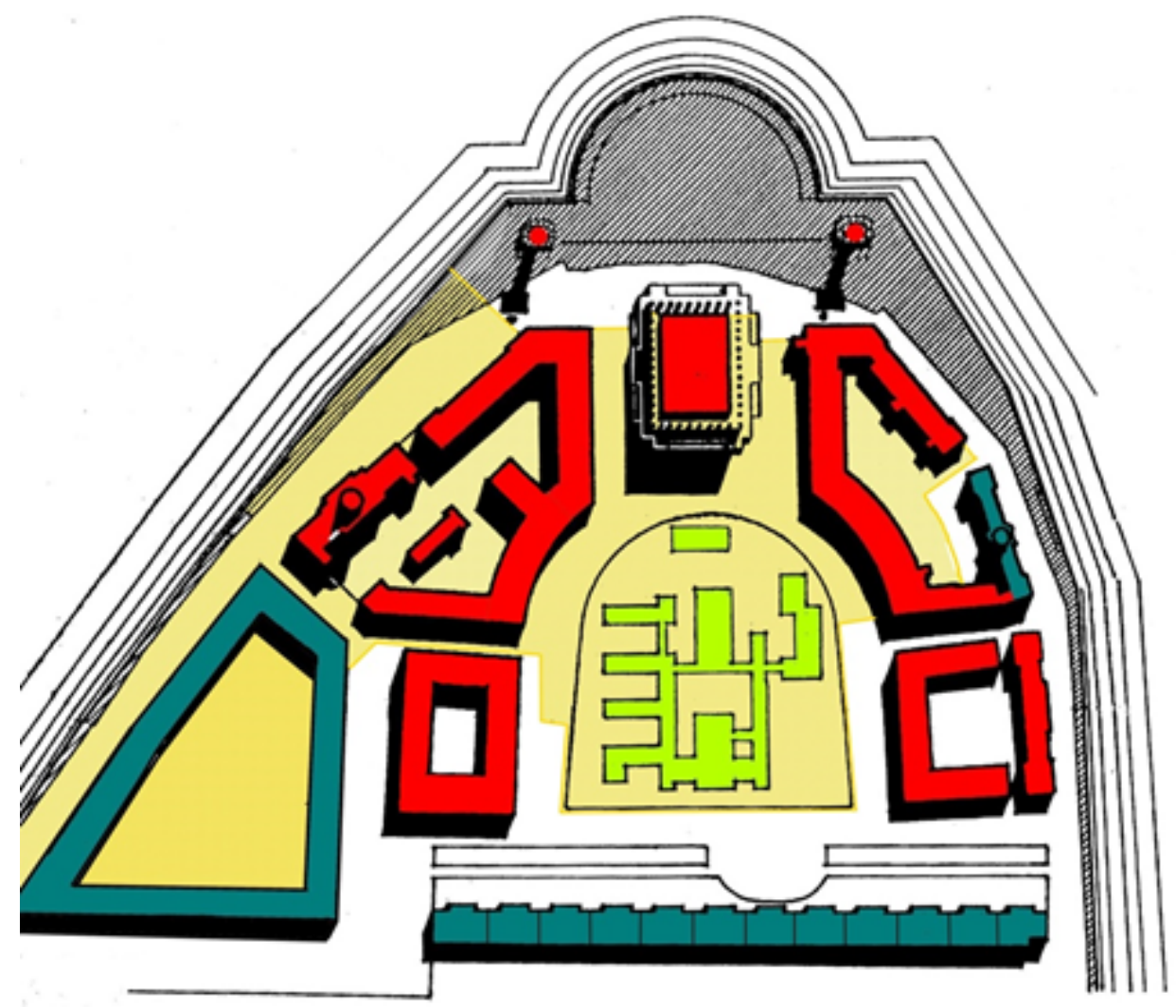

Figure 4. Allocation of trading port and customs facilities at the Spit of Vasilyevsky Island in 1891 (Gruzdeva E.N. Zoological Museum at the Spit of Vasilyevsky Island (according to the documents of Saint Petersburg Branch of the Archive of the Russian Academy of Science) http://www.ranar. spb.ru/files/visual/Zoomuseum/Zoo-5.jpg, access date: 03.06.2018). Yellow color indicates the restricted area of the customs and port. Grey color indicates buildings constructed in the first third of the 18th century; red color - buildings constructed in the first third of the 19th century; green color - buildings constructed in the late 19th century.

and the Kunstkamera was open to all social classes without exception" (https://www.e-reading.club/chapter. php/1011791/4/Sindalovskiy___Sankt-Peterburg_istoriya_v_predaniyah_i_legendah.html). Peter - I repeatedly raised the topic of shops' arrangement. In 1724, the Office of the Emperor wrote: "The intention of His Imperial Majesty was to have shops of Gostiny Dvor (merchant market) around the square as well as in the lower apartments of the collegia on the front side" (http:// artyx.ru/books/item/f00/s00/z0000005/st007.shtml). However, this urban-planning project was not completed.
After the death of Peter I, the development activity in the square began to slow down. The Kunstkamera, Twelve Collegia, and Customs merchant center were managed to be completed, but no shops appeared. There was no movement in the square.

In the end of the 18th century, a new stage of the square development began. In 1783-1797, according to a project of J. Quarenghi, Main Building of the Academy of Sciences, Novobirzhevoy Gostiny Dvor, buildings of the Northern warehouse of the Stock Exchange were constructed. In 1805, Alexander I assigned Thomas de

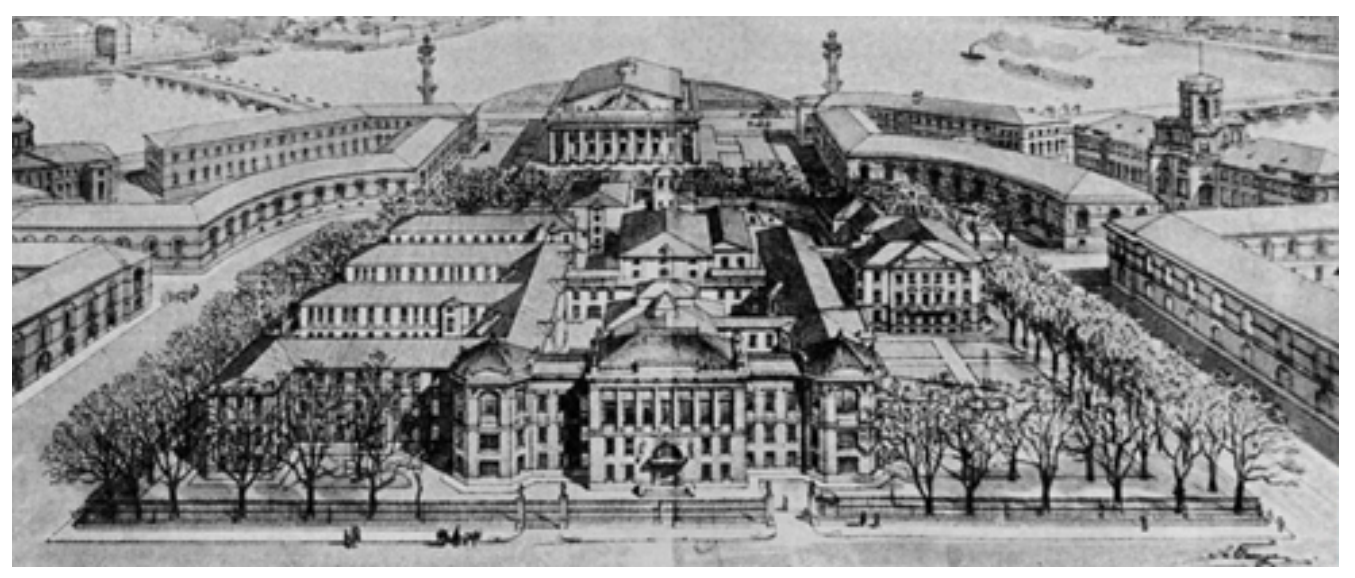

Figure 5. A project for the allocation of Imperial Midwifery Institute buildings at the site of the Customs (Tamozhenny) garden (picture by L. N. Benois). The chimney of the boiler room is conventionally not shown 

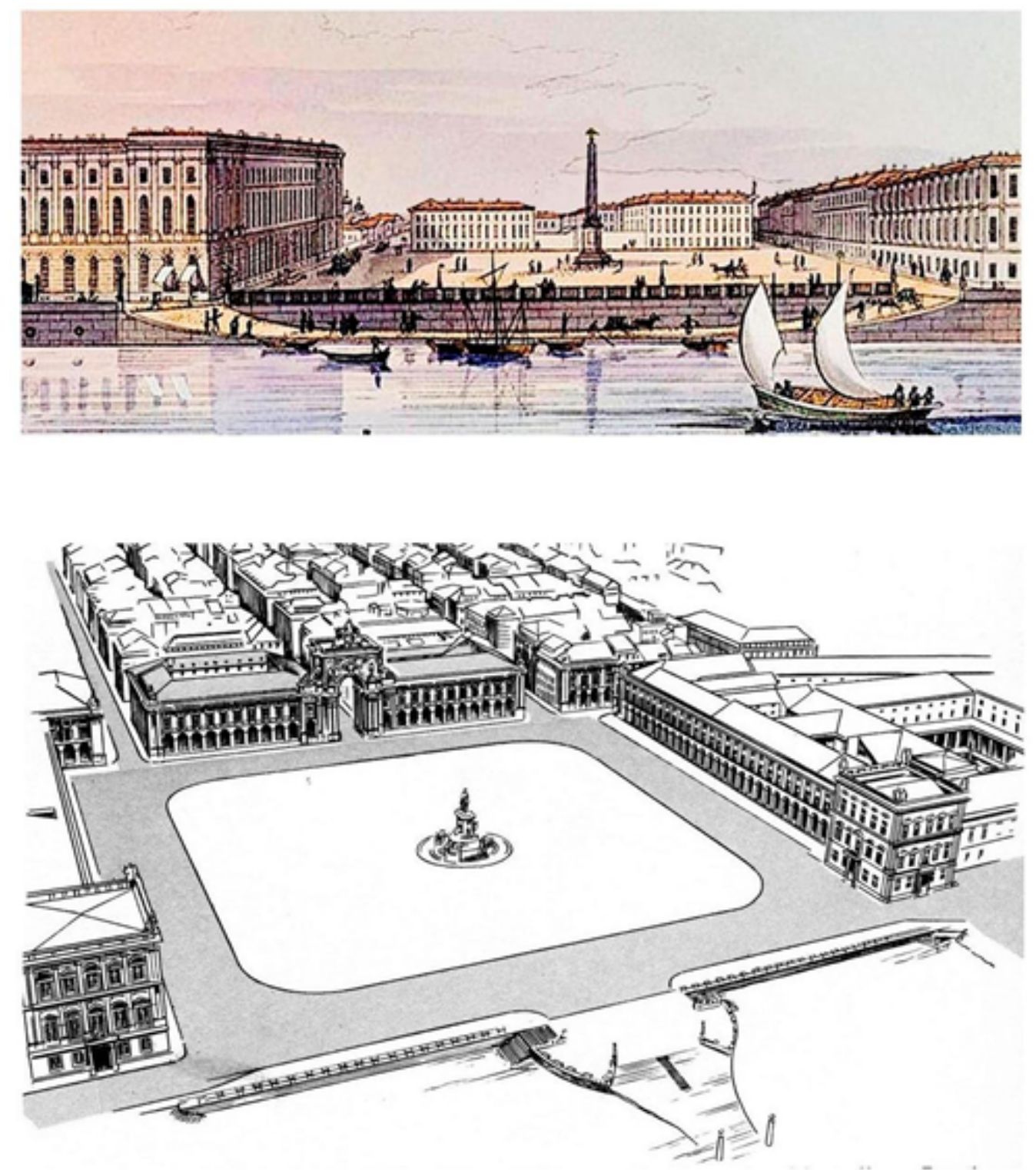

Figure 6. Top: Rumyantsev Square on the banks of the Bolshaya Neva. 1830s. K.P. Beggrov. Lithograph "Academy of Arts and Rumyantsev Obelisk" (fragment) (Nancy Municipal Library. File: Académie des beaux-arts, obélisque Roumiantzoff, album russe de Lisinka Poirel.jpg, access date: 10.07.2018). Bottom: a layout of Praça do Comércio on the banks of the Tagus River in Lisbon (Koch W., 2014)

Thomon to reconstruct the unfinished building of the Stock Exchange at the Spit (a relatively small building with a trading floor of 900 sq. m). The project quickly evolved into a concept of radical landscape changing in the very center of Saint Petersburg. Along with Thomas de Thomon, A. Zakharov, J. Quarenghi, and I. Luchini participated in its development and implementation. They preserved and utilized the heritage left by $D$. Trezzini and G. Chiaveri. An ensemble including Birzhevaya (Stock Exchange) square with a huge semicircular public garden and rostral columns as well as Collegiate square located among the buildings formed.

It could be assumed that by 1830 the dreams of Peter I and $D$. Trezzini about a large regular square like squares of an ideal city came true. It had a symmetrical composition, distinct outlines, and in terms of sizes it was comparable to Palace square. In terms of its artistic and urban-planning features, it was comparable to Mikhailovskaya square in Saint Petersburg, Place Vendôme in Paris. It also had such additional advantage as gaps between the buildings, thanks to which the Neva river could be viewed from there. In the appearance of the buildings, the Petrine Baroque and Alexander's Empire Style were combined, creative ideas of famous architects - D. Trezzini, J. Quarenghi, A.D. Zakharov, Thomas de Thomon, and I.F. Luchini were brought to life.

However, the unique character of this masterpiece of urban-planning art went unnoticed both by townspeople and experts. No images of the square have been preserved. The specifics of its functional purpose manifested: instead of shops intended by Peter I, customs warehouses were located along its perimeter. In 1827, in its central part, a public garden was laid out; later it was decided to use it as a storage area. In order to protect the goods 
from possible floods, the ground level was significantly elevated and a dam system was constructed. Metal grilles were installed in two rows along the perimeter (Nikitenko, Sobol, 2002). Most of the square became a part of the the port's restricted area. It was fenced off due to the customs border and, therefore, became inaccessible to townspeople. Over-sized goods were stored in the area. Temporary overhangs and sheds were built there (Figure 4).

The liquidation of the trading port site at the Spit of Vasilyevsky Island, which occurred in the end of the 19th century, led to a radical change in land use, which was followed by the transformation of the historic buildings. Despite the protests of the creative intelligentsia, the Old Gostiny Dvor was destroyed to clear the site for the construction of a Ministry building. The Academy of Sciences, which got the Southern warehouse, "decorated" its main facade with an overhead portico, and from the opposite side a floor was added, which violated the symmetry of Collegiate square. However, the unique square ceased to exist even in black-and-white layouts as Imperial Midwifery Institute ("Ott's clinic") was built instead of it (Figure 5).

No criticism followed. Perhaps this was due to the fact that it was about the development of the port area or perhaps this was due to the fact that the author of the project was a recognized architect, and the initiator of the construction was the empress herself. These days, Saint Petersburg art experts prefer to avoid analyzing those changes and consider the building as an "exemplary in terms of its functional organization" (Kirikov, 2006).

Moscow experts point out that the design solution was "not absolutely coordinated with the responsible urbanplanning organization," and even the use of the pavilion principle of planning was inappropriate in this case. "The placement of a new large structure in the center of the historic ensemble does not meet the interests of preserving the latter. By occupying the area between the Stock Exchange and the University, the clinic complex disturbed visual connections between the facilities of the ensemble, which made it difficult to perceive it as an integral composition" (Kirichenko, 2010). We have to agree with professor V.G. Lisovsky who refers the reconstruction of the Spit of that period to "urban-planning vandalism" at the turn of the century (Lisovsky, 2004).

\section{Rumyantsev Square}

Rumyantsev square is a typical example of the use of orthogonal system resources for the formation of open public spaces. Some monotony typical for the development of the historic part of Vasilyevsky Island is softened by its direct visual connections with the water area of the Bolshaya Neva. Unfortunately, those few squares that existed in the end of the 18th century and represented a transition stage from river expanses to corridors of streets have disappeared from the map. In particular, J.G. Georgi found it necessary to note that "between the Land Cadet Corps and the Academy of Arts, there is a beautiful unpaved, four-cornered empty space on the right bank of the Neva river" (Georgi, 2001b)..

At first, there was Menshikov market, and then - an on-site area for the Academy of Arts construction. In the 1790s, the territory was used as a parade ground for the Cadet Corps. In 1818, at the suggestion of C. Rossi, Rumyantsev obelisk with a height of more than $20 \mathrm{~m}$ was erected in the center of the square, emphasizing its urbanplanning significance.

The regular space flanked by clearly delineated facades and supplemented by the obelisk was facing the water and became a front square linking the water area of the Bolshaya Neva with Lines 1 and 2 stretching towards the Malaya Neva. The connection of the square with the water was emphasized in the 1830s. For this purpose, the river bank was shaped with a two-tier granite embankment with two symmetrical rampants on the sides. The square and obelisk were perfectly visible from the English Embankment and even from the foot of the Bronze Horseman. The resemblance of Rumyantsev square and Praça do Comércio in Lisbon surprisingly unfolded (Figure 5, 6).

The central square of the Portuguese capital acquired European fame as an example of effective and dynamic reconstruction of the city destroyed by a catastrophic earthquake in 1755. Restored Praça do Comércio (180 x $200 \mathrm{~m}$ ), which used to be considered one of the largest in Europe, is almost the same as Rumyantsev square in terms of size, configuration, compositional symmetry, wide connection of open space with the water area, set of accent elements (a berth on the embankment and a monument in the center). However, the main square of the Portuguese capital was distinguished by luxurious facade decoration.

The situation on the banks of the Neva river changed when the functional load of Rumyantsev square decreased. When cadets stopped marching after the death of Nicholas I, the large unpaved territory became empty. In 1867, at the expense of merchant S.F. Solovyov, the owner of two houses on Rumyantsev square, a garden was laid out in front of his windows. Trees were growing uncontrollably as they were not cut, and over time the overgrown green mass filled most of the square. The green massif was so dense that the 20-meter Rumyantsev Obelisk was visible only through a narrow gap in the central alley of the garden, therefore, in 1913, the Academy of Arts considered the issue of moving the monument to the Field of Mars again (Sindalovsky, 2012). At the present time, this place continues to be designated as a square on the city map, but in fact there has been no open space for a long time.

The dense mass of high greenery fills the area, the functional connections of the garden with the embankment are completely suppressed by traffic flows, the unique potential of view cannot be used. The so-called square can no longer be considered an element of the system of open spaces of the city historic center, and its role in public life has been minimized. 


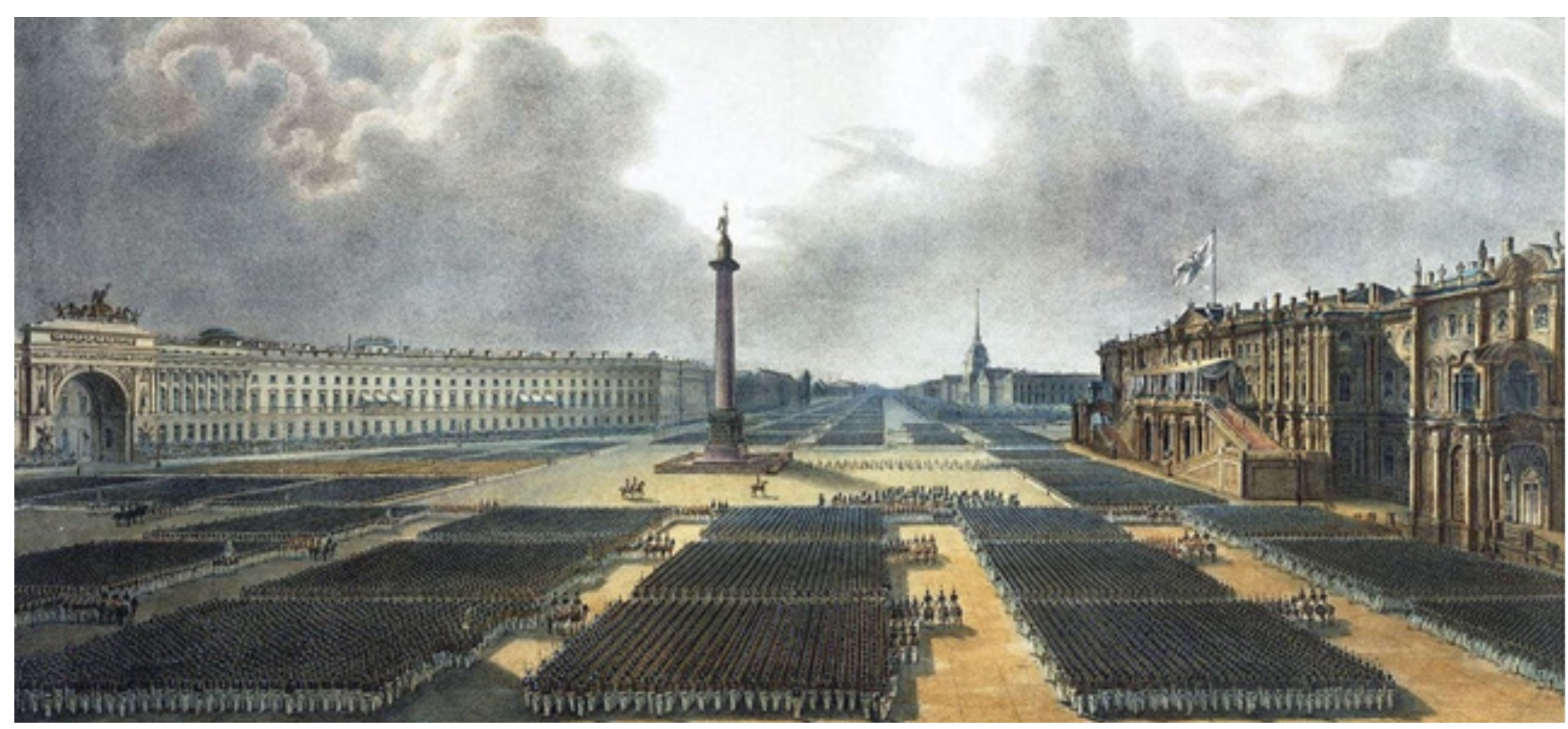

Figure 7. Bichebois, L. P.-A. Bayot A. J.-B. Ceremonial Unveiling of the Alexander Column (fragment) (http://www.hellopiter.ru/Alexandria_pillar_ pic.html)

Central Squares Ensemble on the Admiralty side

Dimensions of this open space formed in the first third of the 19th century in the heart of the Russian capital are unique. As early as in 1794, J.G. Georgi did not pay special attention to those dimensions and, listing squares in the area, he noted a low level of amenities: "irregular Petrovskaya and St. Isaac's squares", "Palace square in the form of an amphitheater" (Georgi, 2001b).

At that time, the Admiralty dominated in the central development on the southern bank of the Neva river. K.P. Batyushkov described it as "a hideous large factory surrounded by drawbridges, deep dirty ditches filled with boards and logs" (Batyushkov, 1978). In 1805, Alexander I decided to start improving the territory adjacent to the Winter Palace. A contemporary of the time described "wild and sorrowful disharmony of the Admiralty that due to the height of the earth mound also seemed lower and darker: the view of that discordant scene was unbearable... The necessity to rebuild this important building did not escape the considerate attention of the Emperor!".

A.D. Zakharov was instructed to suggest options for Admiralty reconstruction. His concept allowed preserving the existing structures in times of austerity to the maximum. He described his idea in a note given to admiral P.V. Chichagov: "During the development of this draft project, my first rule was to secure benefits for the Treasury. Therefore, I decided not to break old walls and foundations, and that is why only several bare walls were added...". The project was approved in 1806, construction works started. Main changes in the existing buildings reflected the unity of functional, structural and aesthetic adjustments:

- window apertures in the existing walls between risalits were immured next but one. It allowed not only enlarging the facade scale but increasing the bearing capacity of the structure and providing a possibility of adding structures;

- with the consideration of the bearing capacity of the existing walls, the height of walls was increased from 9.92 to $16.51 \mathrm{~m}$. It allowed arranging an additional storey and forming the desired proportions of the facade.

As V.G. Lisovsky noted, "due to variations of several forms, Zakharov managed to achieve the sense of wealth and polyphony in the Admiralty architecture" (Lisovsky, 2004).

In parallel with the reconstruction of the Admiralty buildings, reformation of the adjacent territory was performed. According to the Zakharov's project, the canals of the demolished Admiralty Fortress should be reconstructed and have a representative appearance modelled after the Moyka embankments, i.e. the banks should be faced with granite, cast-iron fencing should be installed, and stone bridges should be arched over. However, for economy reasons, the canals were filled up (Shuysky, 1989).

By the beginning of the 1820s, the center of Petersburg transformed radically. A system of large squares formed in place of the former glacis around the Admiralty. Admiralty square appeared in front of the 400-meter main facade. It connected the transformed St. Isaac's and Petrovskaya squares with Palace square. Continuous open spaces embraced the Admiralty from all sides and joined the "main square" of Saint Petersburg which was the majestic water area of the Neva river. This spatial system could be characterized as a core of the city urban-planning skeleton - a "single continuous open space formed by rivers and canals, squares..." (Shvidkovsky, 2007). Streets and canals were stretching to this area commanding a view of the most significant buildings.

While distinguishing architectural advantages of the reconstructed Admiralty, K.P. Batyushkov paid attention to new perspectives: "The Admiralty reconstructed by Zakharov turned into a beautiful building and became an adronment of the city. $\langle\ldots . .>$ The building is surround by a beautiful boulevard with lindens protecting against sun rays. It is the only lovely promenade providing a view of the most majestic and beautiful scenes of Petersburg: the 


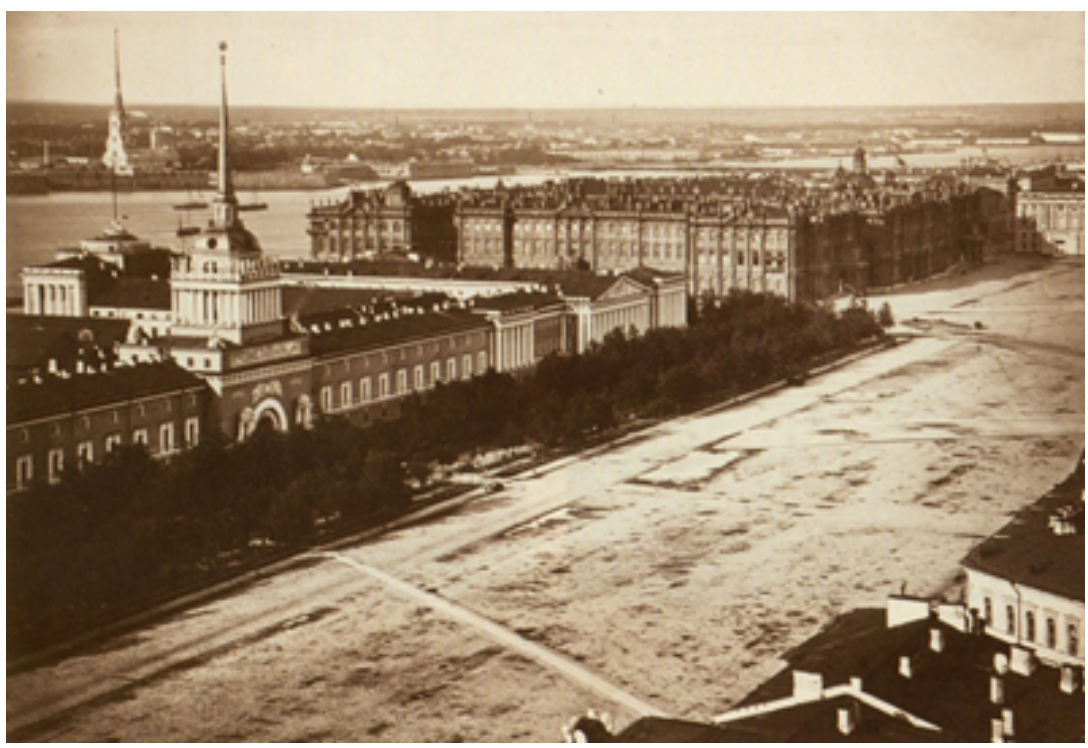

Figure 8 . Admiralty square. A photo of the 1860 s.

Neva river, Winter Palace, splendid buildings of Palace square forming a semicircle, Nevsky prospekt, Saint Isaac's square, Horse Guards Manege reminding of the Pantheon, charming building by Quarenghi, Senate, monument to Peter I and again the Neva river with its embankments!" (Batyushkov 1978).

The scale of this gigantic open space was amazing - it was more than twice larger than the Field of Mars. A huge site - the place where Winter Palace cows pastured a while ago - became an ideal place for ceremonial parades. Canvases of artists of that time show how harmonically infantry squares fit into the designated space (Figure 7).

The Central Squares Ensemble is rightfully considered as an outstanding piece of architectural and urbanplanning art, however, its functional potential was significantly limited. According to Stolpyansky P.N., normally "Admiralty square gave a very bad impression". In proof of his statement he provided the following description of a contemporary: "Most of the day Admiralty square is empty.

One of the newspaper satirists even called it Admiralty prairie as it looks like a cut made inside the capital and filled with historic buildings, but not so vibrant as the center of the outstanding capital should be... Where are people? There are small alternating crowds by public offices (city governor's house thereafter), groups of people on the steps of the Senate and Synod, some carriages, some pedestrians, but that does not satisfy curiosity and a desire to see a spectacular view in the center of Saint Petersburg" (Stolpyansky, 1923). A photo of the 1860s represents the everyday life on central squares (Figure 8).

In 1872, in place of the Admiralty Fortress fortifications, a garden was started. The project was completed by 1874 , "under the enlightened governance of Adjutant General Greig, the President of the Russian Horticultural Society, an expert in botanics; the works were performed by chief botanist of the Imperial Botanical Garden, active state councillor Regel, and collaborating botanists Bergman and Hedwig (Stolpyansky P.N., Old Petersburg. Admiralty island. Labourers Garden. https://coollib.com/b/343277/ read, access date: June 24, 2018). Participation of architects was not reported. Architectural and artistic peculiarities of the site were not considered. The huge urban-planning potential was neglected.

The garden became an impressive display of dendrology treasures in the vast territory in the center of Saint Petersburg but it could not be considered as a landscape architecture artwork. Neither numeour sculptures nor various pavilions and kiosks could save the situation. Flaws in the project became apparent rather quickly. To eliminate those, replanning was performed repeatedly, and in 1890, by order of Alexander III, high overgrown trees were cut out on the land plot around the Bronze Horseman.

In 1902, Razvodnaya ground located between the Admiralty and the Winter Palace was completely transformed (its space was facing the Neva river thus providing visual connections between the river and Palace square). Private (Sobstvenny) Garden (for promenades of imperial family members exclusively) within the safety zone in front of the imperial residence was arranged in this place. Within a short time, the Alexander Garden land plot to the east of the Admiralty was completely liquidated, and the vast territory was enclosed by a massive stone fence with a high grill above. Those structures completely separated the spaces of the central squares from the Neva river. Meanwhile, the anti-terrorist system was non-demanded: the imperial family preferred to stay in Tsarskoye Selo and the Private Garden remained empty (Zimin, 2012).

Famous art expers of that time, who had a chance to see the Central Squares Ensemble in all its glory, noted the significance of city losses:

- I.E. Grabar: "Unfortunately, the entire square in front of the main facade of the Admiralty, which added to the impression that the author wished to make, is planted with garden plants. The square has disappeared, beauty and 

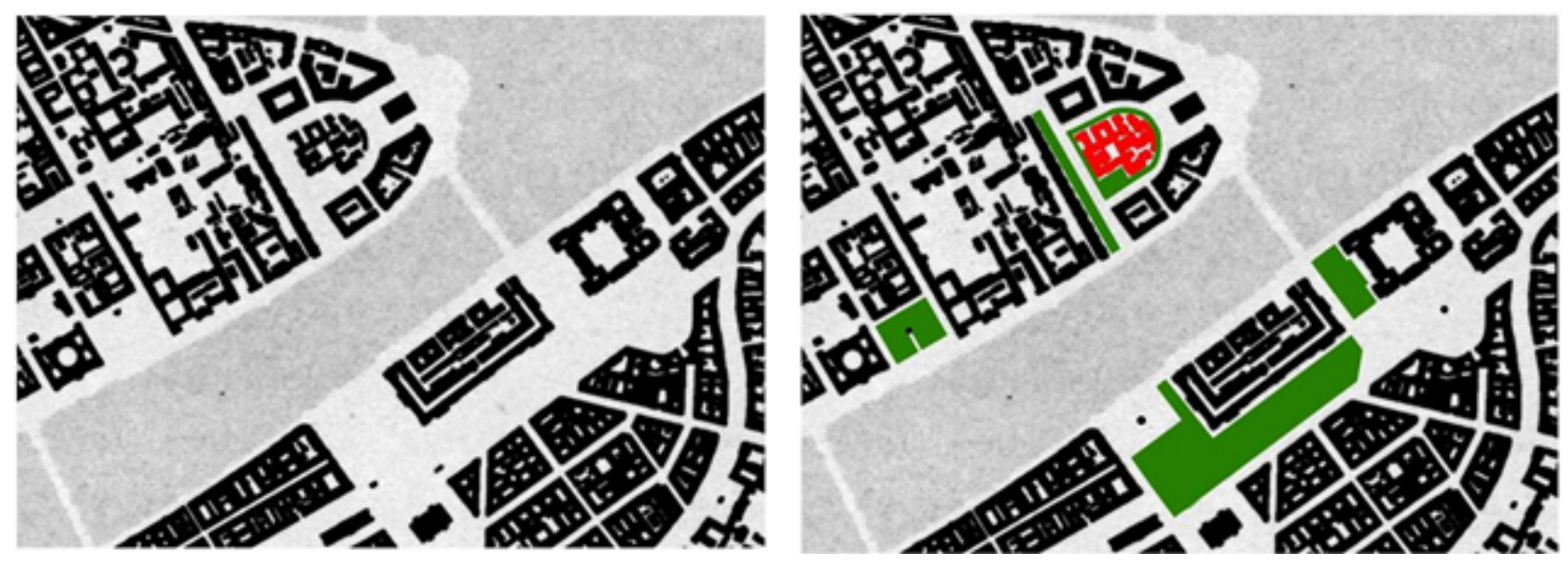

Figure 9. A system of open spaces in Saint Petersburg in 1828-1830 (a fragment of a map by A.L. Mayer (http://www.etomesto.ru/ map-peterburg_1828-city/)

impressiveness of the building have been lost" (Grabar, 1910)

- V.Ya. Kurbatov: "The entire facade of the Admiralty is covered with groves of the poorly planned Alexander Garden... It goes without saying that this structure that exceeds all that was made in the ancient and new world should be more visible. However, most citizens of Saint Petersburg do not have a clue about the beauty of this outstanding artwork of a Russian genius... Its effect was lost for the city when the boulevard was arranged in place of the former ditches (by L. Ruska). Monotonous rows of trees covered the beautiful building, the boulevard did not add to the adornment of the city and did not become a place for promenades (Kurbatov, 1993).

- P. N. Stolpyansky: "The enlarged garden completely covered the facade of the Admiralty, and then it sort of absorbed Senate square. The sight of the Senate and Synod buildings with the arc to the Galernaya Street ceased to amaze; those buildings and the Admiralty itself only lost due to the trees. But if a lawn with low-height bushes was laid out there, it would be a different story" (Stolpyansky, 1923).

- M.I. Roslavlev: "The building of Saint Petersburg Admiralty is the most monumental artwork of the Alexander epoch. This amazing structure has such great history that it is needless to talk about its significance in the city construction. However, the significance of vandalism shall be noted once again. The vandalism was committed by the most recent supervisors of the city development who tolerated the high-height garden on the side of the main facade and square covering by the hideous private buildings and useless alley on the side of the Neva river. I am sure that the Admiralty ensemble and details of this world-famous architectural composition will be restored in the nearest future" (Roslavlev, 1925).

\section{Conclusions}

The study performed showed that the landscape characteristics of the squares' system formed in the 1830 s in the central part of Saint Petersburg around the Neva river water area were fundamentally changed during reconstructions held in the second half of the 19th - early 20th centuries. Senate, Admiralty, Rumyantsev, Collegiate squares and Razvodnaya ground near the Winter Palace lost their transparency. Visual connections between the Neva river expanses and open public spaces were disturbed or suppressed within the city center. This situation is preserved at the present time, that is why the statement that one of the architectural features of the Saint Petersburg historic center is its"single continuous open space formed by rivers and canals, squares, avenues, streets and gardens" (Shvidkovsky, 2007) should be deemed obsolete.

It should be considered that this "distortion of classical ensembles... occurred due to conscious efforts to overcome classicistic standardization", and the main means of transformation was "spreading of green areas over urban spaces" controlled by administrative authorities of the city (Kirikov, 2006).

The increase in a share of green areas could be positively evaluated but this process occurred without the consideration of the urban-planning situation, and landscape architecture considerations were neglected. During this period no palace and park ensembles similar to those that adorned the city and its suburbs in the second half of the 18th century were created. To the contrary, it was marked by significant losses in the city artistic and urban-planning potential. Dense masses of greenery blocked classical panoramas and covered unique facades - an artwork of famous architects.

At the present time, the issue is not addressed properly (as we shoud not speak ill of the past). The main document regulating ways of development and preservation of historic heritage in the city is Decree of the Government of Saint Petersburg No. 1681 "Concerning Saint Petersburg strategy on preservation of cultural heritage" dated November 01, 2005. It is clarified that in our city "cultural heritage protection items include the nature of the environment comprising the planning module of quarters and land plots, scale, height and segmentation of the development". The "unique degree of preservation regarding the Saint Petersburg historic development" is 
documented as well. The condition of open spaces is not considered, resulting in an illusion that the entire modern urban environment should be considered authentic. It is not clarified why the results of the "vandalistic" (Roslavlev M.I.) urban-planning activity in the late 19th - early 20th centuries do not attract any attention and should be considered as having an "integrated value as the Historic Urban Landscape".

Restitution of transparency for all Saint Petersburg squares should become a part of a concept for the prospective development of the "Historic Center of Saint Petersburg" World Heritage Site. An individual program considering individual specifics should be developed for each of them. Upon the resolution of the issue on the fate of the green areas, it is preferable to focus on the natural life cycle of plants, ensure gradual changing of landscape characteristics.

Constant care for the unique ensemble in the central part of Saint Petersburg rather than one-off events shall help the city squares to get rid of the "recent layers" (I.E. Grabar) and "recreate them in the entirety of their architectural and artistic appearance" (. Obviously, it will take some time, but Saint Petersburg is a young city with a long and splendid future ahead. 


\section{References}

Batyushkov, K.P. (1978). Opyty v stikhakh i proze VI. Progulka v Akademiyu KHudozhestv '1814 [Experiments in verse and prose VI. A walk to the Academy of Arts - 1814]. Leningrad: Nauka. (in Russian)

Benois, A.N. (1902). Zhivopisnyj Peterburg [Picturesque Petersburg]. World of Art, 7 (1), pp. 1-5. (in Russian)

Borisova, E.A. (1973). Raboty, Domeniko Trezini po planirovke i zastrojke Strelki Vasil'evskogo ostrova v Peterburge [Works by Domenico Trezzini on planning and development of the Spit of Vasilyevsky Island in Saint Petersburg]. Moscow: Nauka. (in Russian)

Georgi. J.G. (2001a). Opisanie rossijsko-imperatorskogo stolichnogo goroda Sankt-Peterburga. Zdanie Dvenadtsati kollegij [Description of the Russian Imperial capital city Saint Petersburg and the memorable sites in its suburbs, with a map. Twelve Collegia]. Available at: http://www.ipetersburg.ru/zdanie-dvenadcati-kollegiy/ (accessed on 14.05.2018) (in Russian)

Georgi, J.G. (2001b). Opisanie rossijsko-imperatorskogo stolichnogo goroda Sankt-Peterburga [Description of the Russian Imperial capital city Saint Petersburg and the memorable sites in its suburbs, with a map]. Saint Petersburg: Adamant Media Corporation. (in Russian)

Kirichenko, E.I. (2010). Gradostroitel'stvo Rossii serediny XIX - nachala XX stoletiya. Kniga 3. Stolitsy i provintsiya [Town planning in Russia of the mid 19th - early 20th centuries. Volume 3. Capitals and provinces]. Moscow: Progress-Traditsiya. (in Russian)

Kirikov, B.M. (2006). Arkhitektura Peterburga kontsa XIX- nachala XX veka. Eklektika. Modern. Neoklassitsizm [Architecture of Petersburg in the late 19th - early 20th centuries. Eclecticism. Modern. Neoclassicism]. Saint Petersburg: Kolo. (in Russian)

Kurbatov, V.Ya. (1993). Peterburg. Hudozhestvenno-istoricheskij ocherk i obzor hudozhestvennogo bogatstva stolicy [Petersburg. Artistic and historical sketch and review of the artistic wealth of the capital]. Leningrad: Lenizdat. (in Russian)

Lisovsky, V.G. (2004). Arkhitektura Peterburga. Tri veka istorii [Architecture of Saint Petersburg. Three centuries of history]. Saint Petersburg: AO Slaviya. (in Russian)

Nikitenko, G.Yu., Sobol, V.D. (2002). Vasileostrovskij rajon (Entsiklopediya ulits Sankt-Peterburga) [Vasileostrovsky District (Encyclopedia of Saint Petersburg streets)]. Saint Petersburg: Beloye i Chernoye. (in Russian)

Printseva, A. (2016). Cirk v dorevolyucionnoj Rossii [Circus in pre-revolutionary Russia]. Available at: https://arzamas.academy/ mag/294-circus (accessed on: 20.05.2018)

Roslavlev, M.I. (1925). Old Petersburg - New Leningrad. City construction in the past and future. Leningrad: Publishing House of the Academy of Arts.

Shuysky, V.K. (1989). Andreyan Zakharov. Leningrad: Lenizdat. (in Russian)

Shvidkovsky, D. (2007). Russian architecture and the West. New Haven: Yale University Press.

Sindalovsky, N. (1997). Stroitel'stvo Peterburga pri Petre I [Saint Petersburg construction under Peter I]. Saint Petersburg: Norint. (in Russian)

Sindalovsky, N.A. (2012). Legendy peterburgskikh sadov i parkov Rumyantsevskij skver [Legends of Saint Petersburg gardens and parks. Rumyantsev Garden]. Saint Petersburg: Tsentrpoligraf. (in Russian)

Sorokin, P.E., Semenov, S.A. (2003). Arkheologicheskie raskopki u zdaniya Dvenadtsati kollegij v 2000-2002 [Archaeological excavations near the Twelve Collegia in 2000-2002]. Archaeological heritage of Saint Petersburg, 1, pp. 124-159. (in Russian)

Stolpyansky, P.N. (1923). Staryj Peterburg: Admiraltejskij ostrov: Sad trudyashchihsya [Old Petersburg. Admiralty Island. Labourers Garden]. Moscow: GIZ. (in Russian)

Retrospective Statement of Outstanding Universal Value "Historic Centre of Saint Petersburg and Related Groups of Monuments" (1990). Available at: http://kgiop.gov.spb.ru/media/uploads/userfiles/2015/08/24/\%D0\%94\%D\%B5\%D0\%BA\%D0\%BB\% D0\%B0\%D1\%80\%D0\%B0\%D1\%86\%D0\%B8\%D1\%8F_\%D0\%92\%D0\%A3\%D0\%A6.pdf (in Russian)

Zimin, I.V. (2012). Zimnij dvorec. Lyudi i steny. Istoriya imperatorskoj rezidencii. 1762-1917 [Winter Palace. People and walls. History of the Imperial Residence. 1762 1917]. Saint Petersburg: Centrpoligraf. (in Russian) 